\title{
CHARACTERISTICS OF CHRONIC VENOUS ULCERATION RELATED TO AGE
}

\author{
Vesna Karanikolić, Maša Golubović, Nataša Djindjić, Nila Kučar
}

\begin{abstract}
Venous ulceration occurs in $1 \%$ of the total human population, and occurs more often in people older than 65 years. The aim of the study was to determine the characteristics of chronic venous ulceration (CVU) related to the patients age. The study included 102 ambulatory patients with CVU, treated at the Clinic of Skin Diseases of the Clinical Center Niš. The study group consisted of patients $\geq 65$ years, while the control group consisted of patients $<65$ years. The study used patients' data such as age, gender, history of deep vein thrombosis, previous episodes of ulceration, previous operation on the veins, body mass index, calf circumference (CC), number of ulcerations, ulceration localization, ulcer size, duration of the ulcer and ulcer locoregional characteristics. Patients aged $\geq 65$ years had longer incidence of ulceration and a larger number of previous episodes of ulceration. In patients aged $\geq 65$ years, calf circumference was statistically higher, which can significantly affect the speed and healing rate. Larger surface area were more commonly reported in patients aged $<65$ years with statistically significant $p<0.05$, while elderly patients had statistically $(p<0.01)$ prolonged ulceration. Concerning the locoregional characteristics of CVU, dermatitis was more commonly seen in patients aged $\geq 65$ years, while lipodermatosclerosis was more prevalent in patients aged $<65$ years. In relation to the wound infection, patients aged $\geq 65$ years had a statistically higher prevalence of ulcer infections. Elderly patients with CVU represent a distinct group in terms of aetiology, natural history and prognosis.
\end{abstract}

Acta Medica Medianae 2020;59(1):71-75.

Key words: chronic leg ulceration, venous ulceration, the elderly

Clinic of Dermatology, Clinical Center Niš, Serbia

Contact: Vesna Karanikolić

48 Dr. Zoran Djindjić Blvd., 18000 Niš, Serbia

E-mail: pean@ptt.rs

\section{Introduction}

Venous ulceration is one of the most common vascular diseases in the human population. It arises as a complication of chronic venous insufficiency. Chronic venous insufficiency is responsible for the occurrence of about $70 \%$ of chronic ulcerations of the lower extremities, especially those that do not heal within 6 weeks (1).

Venous ulceration occurs in $1 \%$ of the total human population, and occurs more often in people older than 65 years of age. The ratio of presentation shows a significantly higher proportion of women in the ratio of $3: 1$ (women: men) (2-5).

Chronic venous ulceration (CVU) occurs in $0.6-3 \%$ of the population over 60 years and in patients over 80 years the percentage increases by another $5 \%$. Chronic venous ulceration is a common cause of morbidity and their prevalence in human population range from $1.9 \%-13.1 \%(6-10)$. The incidence of ulceration is thought to increase as a result of aging and increased factors for atherosclerosis, such as smoking, obesity, and diabetes are also responsible. During the life, almost $10 \%$ of the population can develop a chronic wound, with a mortality of $2.5 \%$ (10).

The aim of the study was to determine the characteristics of CVU related to the patient's age.

\section{Materials and methods}

The study included 102 ambulatory patients aged over 18 years with a CVU, treated at the Clinic for Skin Diseases of the Clinical Center Niš. The study lasted from April 2015 to February 2016. According to the age, patients were divided into two groups. The study group consisted of patients $\geq 65$ years of age, while the control group consisted of patients $<65$ years of age.

Before joining the study, all patients were subjected to Doppler ultrasound (DUS) examination in order to evaluate the venous and arterial leg system. The ankle-brachial pressure index (ABPI) was measured in all patients. Venous aetiology of 
ulceration was verified by DUS. Patients with venous ulcerations over $3 \mathrm{~cm}^{2}$ and duration of illness of over 3 months were involved in the examination.

Patients with ABPI $<0.8$, with cardiac insufficiency (ejection fraction < 35), pregnant women, patients with malignant diseases, diabetes, patients on immunosuppressive and cortical therapy were excluded from the study.

Patients who had ulcerations associated with skin vasculitis, pyoderma gangraenosum and other neutrophilic dermatoses were excluded from this study.

The study used patients' data such as age, gender, history of deep vein thrombosis, previous episodes of ulceration, previous operation on the veins, body mass index (BMI), calf circumference (CC), number of ulcerations, ulceration localization, ulcer size (US), duration of the ulcer. The study also used information regarding dermatitis, lipodermatosclerosis and ulcer infection as locoregional characteristics of ulcerations.

Determination of the dimensions of the ulceration was performed by measuring the maximum width and length of ulceration, as well as by computerized process, which consists of mapping the two-dimensional digital image onto the polygonal mesh.

The calf and ankle circumference were measured in the recumbent position with the maximal (calf) and the minimal (ankle) point determined visually.

Doppler scan was used to standardize the superficial, perforated and deep venous system of the lower extremities. Venous reflux greater than $1 \mathrm{~s}$ was considered significant.

The reflux was categorized into three groups: presence of superficial reflux only; additional presence of one or more insufficient perforating calf veins, but no deep venous reflux; or the presence of deep venous reflux at any level of the cru-femoral axis, with or without varicose veins.

\section{Data analysis}

Values are expressed as the mean \pm standard deviations (SD). Differences among groups were examined by Mann-Whitney Rank Sum Test, Chisquare test and by Fisher exact test (Jandel Sigma Stat, version 2).

Table 1. Comparison of patients developing chronic venous ulcerations in relation to age

\begin{tabular}{|c|c|c|c|}
\hline Variable & Age $<65(n=51)$ & Age $\geq 65(n=51)$ & p - value \\
\hline \multicolumn{4}{|c|}{ Gender } \\
\hline Male; n (\%) & $24(47.05 \%)$ & $23(45.1 \%)$ & n.s. \\
\hline Female; n (\%) & $27(52.95 \%)$ & $28(55.9 \%)$ & n.s. \\
\hline \multicolumn{4}{|c|}{ Age } \\
\hline (mean \pm SD) & $52.81 \pm 6.60$ & $71.88 \pm 5.76$ & n.a \\
\hline Medijana (rank) & $53(42-64)$ & $70(65-85)$ & n.a \\
\hline \multicolumn{4}{|c|}{ History of deep vein thrombosis } \\
\hline n (\%) & $21(41.17 \%)$ & $22(43.14 \%)$ & n.s. \\
\hline \multicolumn{4}{|c|}{ Previous episodes of ulceration } \\
\hline n (\%) & $31(60.78 \%)$ & $45(88.23 \%)$ & $<0.01$ \\
\hline \multicolumn{4}{|c|}{ Previous operations } \\
\hline$n(\%)$ & $18(35.29 \%)$ & $16(31.37 \%)$ & n.s. \\
\hline \multicolumn{4}{|c|}{ Body mass index } \\
\hline$($ mean \pm SD) & $32.40 \pm 1.34$ & $29.99 \pm 1.68$ & n.s. \\
\hline \multicolumn{4}{|c|}{ Calf circumference $(\mathrm{cm})$} \\
\hline$($ mean \pm SD) & $34.67 \pm 6.23$ & $38.56 \pm 5.34$ & $<0.05$ \\
\hline \multicolumn{4}{|c|}{ Number of the ulcers } \\
\hline n(\%) & $44(88 \%) a ; 7(12 \%) b$ & $40(76 \%) a ; 11(24 \%) b$ & n.s. \\
\hline \multicolumn{4}{|c|}{ Localisation of the ulcers } \\
\hline (right leg) n (\%) & $24(47.06 \%)$ & $24(47.06 \%)$ & n.s. \\
\hline \multicolumn{4}{|c|}{ Size of the ulcer $(\mathrm{cm} 2)$} \\
\hline$($ mean $\pm S D)$ & $16.99 \pm 10.31$ & $12.1 \pm 5.86$ & $<0.05$ \\
\hline \multicolumn{4}{|c|}{ Duration of the ulcer } \\
\hline$(y r s \pm S D)$ & $6.54 \pm 3.68$ & $12.16 \pm 6.23$ & $<0.01$ \\
\hline \multicolumn{4}{|c|}{ Superficial reflux only } \\
\hline $\mathrm{n}(\%)$ & $2(3.92 \%)$ & $1(1.96 \%)$ & n.s. \\
\hline \multicolumn{4}{|c|}{ Perforating vein incompetence } \\
\hline $\mathrm{n}(\%)$ & $30(58.82 \%)$ & $30(58.82 \%)$ & n.s. \\
\hline \multicolumn{4}{|c|}{ Deep venous reflux } \\
\hline$n(\%)$ & $22(43.14 \%)$ & $21(41.17 \%)$ & n.s. \\
\hline \multicolumn{4}{|c|}{ Dermatitis } \\
\hline $\mathrm{n}(\%)$ & $23(45.1 \%)$ & $29(56.86 \%)$ & $<0.05$ \\
\hline \multicolumn{4}{|c|}{ Lipodermatosclerosis } \\
\hline $\mathrm{n}(\%)$ & $30(58.82 \%)$ & $16(31.37 \%)$ & $<0.01$ \\
\hline \multicolumn{4}{|c|}{ Infection } \\
\hline n (\%) & $30(58.82 \%)$ & $37(72.55 \%)$ & $<0.05$ \\
\hline
\end{tabular}

Abbreviations: BMI - body mass index; $a$ - one ulcer; $b$ - two ulcers

*Mann-Whitney Rank Sum Test; tChi-square test; n.s. - not significant, n.a. - not applicable 


\section{Results}

Both the investigated group, age $\geq 65$, and the control group, age $<65$, had 51 patients. The average age of the age $<65$ group was 53 years, while the average age of the age $\geq 65$ group was 70 years. There was no statistically significant difference between sex and history of deep vein thrombosis. Somewhat higher representation of CVU was in the female population. Previous episodes of ulceration were statistically more common in the age $\geq 65$ group ( $p>0.01$ ). Concerning previous operations on the venous system and body mass index values, the number of ulceration and localization of ulceration did not have a statistically significant difference between the examined and the control group of patients. Calf circumference was statistically higher $p<0.05$ in the age $\geq 65$ group. Larger surface area were more commonly reported in patients aged < 65 years with statistically significant $p<0.05$, while elderly patients aged $\geq 65$ years had statistically ( $p<0.01$ ) longer prolonged ulcerations. There was no statistically significant difference in surface reflux only, perforating vein incompetence and deep venous reflux among examined groups. Concerning the locoregional characteristics of CVU, dermatitis was more prevalent in patients aged $\geq 65$ years ( $p<0.05)$, while lipodermatosclerosis was more prevalent in patients aged $<65$ years ( $p<$ 0.01 ). In relation to the infection of ulcers, statistically higher prevalence was found in the age $\geq$ 65 group $(p<0.05)$ (Table 1$)$.

\section{Discussion}

Venous leg ulcers are one of the most common vascular diseases in human populations. Venous ulcer represents the clinical expression of decompensated chronic venous insufficiency. The average age of patients with chronic venous ulcers is between 50 and 60 years, out of which $55 \%$ of patients are female and $45 \%$ male (11). Venous ulceration occurs most commonly in patients older than 65 years, although the incidence and prevalence of chronic venous ulceration in the elderly population is not well established. The study of Margolis et al. (12) aimed to highlight the prevalence and incidence of chronic venous ulceration in the population of patients over 65 years of age. Data are obtained from the primary health care register. The annual prevalence of venous ulceration among the older population was 1.69. The overall incidence of venous ulceration was 0.76 for men and 1.42 for women. The study showed that chronic venous ulceration is a significant health problem in elderly patients.

In our study, the female gender was somewhat more represented. The average age of patients in the age < 65 group was 53 years, while in the age $>65$ group it was 70 years.

A study by MacKenzie et al. (13) showed that patients who developed CVU before their $50^{\text {th }}$ birth- day were more likely to be male, obese, had a worse disease that appeared less responsive to treatment and had a history of deep vein thrombosis (DVT) and/or long bone fracture suggesting a post-thrombotic aetiology. The proportion of CVUs that are post-thrombotic in aetiology remains controversial. However, recent data suggesting that up to $50 \%$ of all CVU patients have at least one thrombophilia suggests that previous, often unrecognized DVT probably plays a significant role in the development of a larger proportion of ulcers than previously appreciated.

There was no statistically significant difference between sex groups and history of deep vein thrombosis. Higher representation of CVU was in the female population. Previous episodes of ulceration were statistically more common in the age $\geq 65$ group ( $p>0.01$ ). Concerning previous operations on the venous system and body mass index values, the number of ulceration and localization of ulceration did not have a statistically significant difference between the examined and the control group of patients. Calf circumference was statistically higher ( $p<0.05$ ) in the age $\geq 65$ group of patients. Several studies $(11,14)$ showed the importance of calf circumference in healing CVU. Calf circumference $<33 \mathrm{~cm}$ represents a positive predictor for successful healing of venous ulceration, and patients with a larger calf circumference represent a risk group and require more intensive and prolonged therapy.

A number of studies were concerned with the presence of chronic venous disorders, surgery on the venous system and their effect on the healing effect of chronic venous ulceration in patients with the use of a multiplex compressive bandage. Also, dermatological local characteristics of venous ulceration were monitored for their presence and influence on the effectiveness of healing chronic venous ulceration in patients with the applied multilayer compressive bandage. $(1,11,14)$

Large-area ulceration was more common in age $<65$ with statistically significant $p<0.05$, while elderly patients age $\geq 65$ had statistically ( $p<0.01$ ) prolonged ulceration.

In summary, patients aged $\geq 65$ years had longer incidence of ulceration and a larger number of previous episodes of ulceration. In patients aged $\geq 65$ years, calf circumference was statistically higher, which can significantly affect the speed and effectiveness of healing of CVU. Larger surface area were more commonly reported in patients aged < 65 years with statistically significant $p<0.05$, while elderly patients had statistically ( $p<0.01$ ) prolonged ulceration. Concerning the locoregional characteristics of CVU, dermatitis was more commonly seen in patients aged $\geq 65$ years, while lipodermatosclerosis was more prevalent in patients aged $<65$ years. In relation to the wound infection, patients aged $\geq 65$ years had a statistically higher prevalence of infections. 


\section{References}

1. Karanikolic V, Karanikolic A, Petrovic D, Stanojevic M. Prognostic factors related to delayed healing of venous leg ulcer treated with compression therapy. Dermatologica Sinica 2015;33(4):206-9.[CrossRef]

2. Grover G, Tanase A, Elstone A, Ashley S. Chronic venous leg ulcers: Effects of foam sclerotherapy on healing and recurrence.Phlebology 2014.31(1):34-41. [CrossRef][PubMed]

3. Bradbury AW, Evans CJ, Allan PL, Lee AJ, Ruckley CV, Fowkes FGR. What are the symptoms of varicose veins? Edinburgh vein study cross sectional population survey. Br Med J 1999;318(7180):353-6. [CrossRef][PubMed]

4. Evans CJ, Fowkes FGR, Ruckley CV, Lee AJ. Prevalence of varicose veins in men and women in the general population: Edinburgh Vein Study. J Epidemiol Community Health 1999;53(3):149-53. [CrossRef][PubMed]

5. Allan PL, Bradbury AW, Evans CJ, Lee AJ, Ruckley CV, Fowkes FGR. Patterns of reflux and severity of varicose veins in the general population - Edinburgh Vein Study. Eur J Vasc Endovasc Surg 2000; 20(5):470-7.[CrossRef][PubMed]

6. MacKenzie RK, Paisley A, Allan PL, Lee AJ, Ruckley CV, Bradbury AW. The effect of long saphenous vein stripping on quality of life. J Vasc Surg 2002;35(6): 1197-203.[CrossRef][PubMed]

7. Phillips TJ. Chronic cutaneous ulcers: etiology and epidemiology. J Invest Dermatol 1994;102(6):38S41S. [PubMed]
8. Chatterjee SS. Venous ulcers of the lower limb: where do we stand? Indian J Plast Surg 2012;45(2):266-74. [PubMed]

9. Amir O, Liu A, Chang ALS. Stratification of highest-risk patients with chronic skin ulcers in a Stanford retrospective cohort includes diabetes, need for systemic antibiotics, and albumin levels. Ulcers 2012; ID 767861. [CrossRef]

10. Rayner R, Carville K, Keaton J, Prentice J, Santamaria $\mathrm{XN}$. Leg ulcers: atypical presentations and associated co-morbidities. Wounds 2009;17(4):168-85.

11. Karanikolic V, Binic I, Jovanovic D, Golubovic M, Golubovic I, Djindjic N, et al. The effect of age and compression strength on venous leg ulcer healing. Phlebology 2018;33(9):618-26.[CrossRef][PubMed]

12. Margolis D, Bilker W, Santanna J, Baumgarten M. Venous leg ulcer: Incidence and prevalence in the elderly. J Am AcadDermatol 2002;46(3):381-6. [CrossRef][PubMed]

13. MacKenzie RK, Brown DA, Allan PL, Bradbury AW, Ruckley CV. A comparison of patients who developed venous leg ulceration before and after their $50^{\text {th }}$ birthday. Eur J Vasc Endovasc Surg 2003;26(2):1768. [CrossRef][PubMed]

14. Milic DJ, Zivic SS, Bogdanovic DC, Jovanovic MM, Jankovic RJ, Milosevic ZD, et al. The influence of different sub-bandage pressure values on venous leg ulcers healing when treated with compression therapy. J Vasc Surg 2010;51(3):655-61. [CrossRef][PubMed] 


\title{
KARAKTERISTIKE HRONIČNE VENSKE ULCERACIJE POVEZANE SA STAROŠĆU
}

\author{
Vesna Karanikolić, Maša Golubović, Nataša Đinđić, Nila Kučar
}

Klinika za dermatologiju, Klinički centar Niš, Niš, Srbija

Kontakt: Vesna Karanikolić

Bulevar dr Zoran Đinđić 48, 18000 Niš, Srbija

E-mail: pean@ptt.rs

Venska ulceracija javlja se kod $1 \%$ ukupne humane populacije, a češće se javlja kod osoba starijih od 65 godina. Cilj studije bio je da se odrede karakteristike hroničnih venskih ulceracija (CVU) u odnosu na starosnu dob bolesnika. Studijom su obuhvaćena 102 ambulantna bolesnika sa CVU, lečena na Klinici za kožne bolesti Kliničkog centra Niš. Studijska grupa sastojala se od bolesnika koji su imali 65 ili više godina, dok su kontrolnu grupu činili bolesnici mlađi od 65 godina. U studiji su korišćeni podaci bolesnika kao što su starost, pol, istorija duboke venske tromboze, prethodne epizode ulceracije, prethodna operacija na venama, indeks telesne mase, obim gležnja (CC), broj ulceracija, lokalizacija ulceracije, veličina ulceracija, trajanje ulceracija i lokalne karakteristike ulceracija. Bolesnici od 65 i više godina imali su dužu istoriju ulceracija, kao i veći broj prethodnih epizoda ulceracija.

Kod bolesnika starijih od 65 godina obim gležnja bio je statistički veći, što može znatno uticati na brzinu i efikasnost lečenja. Veća površina javlja se kod bolesnika starosne dobi manje od 65 godina sa statističkom značajnošću $(p<0,05)$, dok su stariji bolesnici imali dužu istoriju ulceracija $(p<0,01)$. Što se tiče lokalno-regionalnih karakteristika CVU, dermatitis se češće javlja kod bolesnika starijih od 65 godina, dok je lipodermatoskleroza bila preovlađujuća kod bolesnika starijih od 65 godina. U odnosu na infekciju rane, bolesnici koji su imali 65 ili više godina imali su statistički veću prevalenciju infekcija ulceracija. Stariji bolesnici sa CVU predstavljaju posebnu grupu u smislu etiologije, istorije i prognoze bolesti.

Acta Medica Medianae 2020;59(1):71-75.

Ključne reči: hronične ulceracije nogu, venska ulceracija, starije osobe 